\title{
Breakdown of peptides from a casein hydrolysate by rumen bacteria. Simultaneous study of enzyme activities and physicochemical parameters
}

\author{
N Depardon, D Debroas *, G Blanchart ** \\ Laboratoire de sciences animales, Ensaia-Inra, 2, avenue de la Forêt-de-Haye, BP 172, \\ 54505 Vandcuvre, France
}

(Received 3 May 1994; accepted 20 June 1996)

\begin{abstract}
Summary - The breakdown of a pancreatic hydrolysate of casein (tryptone) by an inoculum of ruminal mixed bacteria was studied in vitro. Peptides were degradated at $33 \%$ after $5 \mathrm{~h}$. The dipeptidyl aminopeptidase type I (DAP-1), exoaminopeptidase and leucine aminopeptidase (LAP) like activities were measured using, respectively, Gly-Arg-MNA, Ala-pNa and Leu-pNA as substrates. While the total proteolytic activity remained stable throughout peptide breakdown, the DAP-1 already present at the beginning of fermentation increased until two times its early activity. This peptidase activity is a major index for the presence of Prevotella ruminicola. A peak of exoaminopeptidase and LAP activities were observed at $3 \mathrm{~h}$ incubation. This latter activity, which was associated with the production of lactate after $3 \mathrm{~h}$, suggested that Streptococcus bovis was present in the environment. With the use of high-performance size exclusion chromatography (HPSEC), the size of the peptides during their breakdown could be measured, showing that high molecular weight peptides ( 4 to $2 \mathrm{kDa}$ ) were apparently more rapidly broken down to the profit of small-sized peptides $(<0.5 \mathrm{kDa})$, which increased. These degradation abilities were closely linked to DAP-1 activity. Separation of tryptone peptides by reverse-phase high-performance liquid chromatography (HPLC) showed that more hydrophilic peptides disappeared than hydrophobic peptides. Moreover, a few peaks eluting for one in the hydrophilic area and for the others in the hydrophobic area resisted the bacterial breakdown. In contrast, amino acid profiles indicated that hydropholic amino acids were not taken up significantly faster than the hydrophobic amino acids by mixed ruminal bacterial.
\end{abstract}

rumen bacteria / proteolysis / peptides / hydrophobicity / size / aminopeptidases

Résumé - Évolution de la taille et de l'hydrophobicité des peptides au cours de leur dégradation par les bactéries du rumen. Une étude cinétique est réalisée in vitro sur la dégradation d'un hydrolysat pancréatique de caséine (Tryptone) par un inoculum de bactéries libres du rumen. Les peptides sont hydrolysés à $33 \%$ après 5 heures. Les activités dipeptidyl aminopeptidasique de type I (DAP-1). exoaminopeptidasique et leucine aminopeptidasique (LAP) sont mesurées à l'aide des substrats GlyArg-MNA, AlapNA et LeupNA, respectivement. L'activité protéolytique totale reste stable au cours de la fermentation. L'activité DAP-1 est deux fois plus élevée en fin de cinétique qu'en début de fermen-

* Present address: Laboratoire de biologie comparée des protistes, Ura CNRS 1944, université Blaise-Pascal, 63177 Aubière cedex, France

** Correspondence and reprints 
tation. Cette activité peptidasique est un indice majeur de l'intervention de Prevotella ruminicola. Les activités exoaminopeptidasique et LAP présentent un maximum d'activité après 3 heures d'incubation. $L$ 'activité $L A P$, associée à une forte production de lactate à 3 heures pourrait indiquer la présence de Streptococcus bovis dans le milieu. Le suivi de la taille des peptides au cours de leur dégradation, effectué par HPLC-gel filtration, montre que les peptides de hauts poids moléculaires (2 à $4 \mathrm{kDa}$ ) sont apparemment dégradés le plus rapidement et ceci au profit de petits peptides $(<0,5 \mathrm{kDa})$. Cette dégradation pourrait être essentiellement due à la DAP-1. La séparation des peptides par HPLC phase-inverse met en évidence une disparition préférentielle des peptides hydrophiles vis-à-vis des peptides hydrophobes. Par ailleurs des peptides ayant des degrés d'hydrophobicité très différents n'ont pas subi de dégradation. L'analyse de la composition en acides aminés ne confirme pas la dégradation préférentielle des acides aminés hydrophiles par rapport aux acides aminés hydrophobes.

bactéries du rumen / protéolyse / peptides / hydrophobicité / taille / aminopeptidases

\section{INTRODUCTION}

Peptides are intermediates in the conversion of ingested protein to ammonia by rumen bacteria and are a site at which the rate of breakdown might be controlled (Wallace et al, 1990b). Previous studies indicated that peptides were broken down in rumen fluid almost exclusively by aminopeptidases. Using different synthetic substrates, the dipeptidyl aminopeptidase type I (DAP1; EC 3.4.14.1) (Wallace and McKain, 1989; Wallace et al, 1990a) and the exoaminopeptidase activities have been identified as playing a predominant role in peptide hydrolysis. Numerous studies carried out on peptide metabolism by rumen microorganisms have recently demonstrated the effect of two parameters on peptide catabolism: peptide hydrophobicity and size.

Hydrophobicity was first studied by Chen et al (1987c) using a pancreating hydrolysate of casein (tryptone). Hydrophobic and hydrophilic peptides were separated by simple extraction with isopropanol. Kinetic studies performed in vitro have shown that the bacteria had the same affinity for both fractions but broke down hydrophilic peptides twice as rapidly as hydrophobic peptides. The response was identical using pure or mixed bacterial cultures (Chen et al, 1987c). Several attempts have been made to analyze the extracellular peptides of the ruminal fluid by reversed-phase high-perfor- mance liquid chromatography (HPLC) (Russel et al, 1983; Chen et al, 1987a,b). Interpretation of the chromatograms was difficult except in the study of Chen et al (1987b) where hydrophilic peptides (eluted in the first part of the chromatogram) seemed to be preferentially used by rumen microorganisms. The more hydrophobic fractions were rarely or not broken down during the $17 \mathrm{~h}$ with the exception of a late emerging peak that decreased. This could indicate that even hydrophobic peptides might be used.

Wright (1967) has shown that small peptides and amino acids were converted to VFA more rapidly than high molecular weight peptides ( $>2 \mathrm{kDa}$ ), but that the latter were incorporated preferentially into bacterial protein. More recently, Copper and Ling (1985) demonstrated that high molecular weight peptides were incorporated into microbial proteins more rapidly than the smallest peptides. Different studies have thus evidenced the influence of the size of peptides on their metabolism by rumen bacteria.

The aim of the present work was to study the metabolism of peptides by an inoculum of rumen bacteria. The main factors studied were the molecular weight and the hydrophobicity of residual peptides as well as some of the major peptidase activities. In this first investigation we chose to study these parameters with tryptone peptides, which is a substrate commonly used in the literature. Such a simultaneous study of 
physicochemical parameters - such as hydrophobicity and peptide size - and peptidase activities has never been carried out.

\section{MATERIALS AND METHODS}

\section{Animals, diet and sample preparation}

Ruminal contents were obtained from a ruminally fistulated goat, fed twice daily $500 \mathrm{~g}$ of grass hay and $250 \mathrm{~g}$ of a dried alfalfa. At $1.5 \mathrm{~h}$ after feeding, a ruminal fluid sample was taken and flushed with $\mathrm{CO}_{2}$. Large feed particles and protozoa were removed by slow speed centrifugation $(150 \mathrm{~g}, 20$ $\left.\min , 15^{\circ} \mathrm{C}\right)$. The supernatant was centrifuged at a higher speed $\left(6000 \mathrm{~g}, 30 \mathrm{~min}, 15^{\circ} \mathrm{C}\right)$ in order to havest the rumen bacteria. The bacterial pellet was resuspended in $30 \mathrm{~mL}$ anaerobic medium without peptides source, as described later.

\section{Incubation with peptides in vitro}

The anaerobic culture techniques used were similar to those described by Hungate (1969). One liter of medium contained $230 \mathrm{mg} \mathrm{K} \mathrm{HPO}_{4}$, $456 \mathrm{mg} \mathrm{NaCl}, 230 \mathrm{mg} \mathrm{KH}_{2} \mathrm{PO}_{4}, 45.6 \mathrm{mg} \mathrm{CaCl}_{2}$, $95 \mathrm{mg} \mathrm{MgSO}_{4}, 10 \mathrm{~mL}$ of Pfennig's micromineral solution (Schaefer et al, 1980), $1 \mathrm{mg} \mathrm{Hemin}$, $30 \mathrm{mmol}$ acetate, $8 \mathrm{mmol}$ propionate, $3 \mathrm{mmol}$ butyrate and $0.1 \mathrm{mmol}$ each of isobutyrate, isovalerate, 2-methyl-butyrate, $1 \mathrm{~mL}$ of a solution of vitamins (Russell et al, 1983), $2500 \mathrm{mg}$ glucose, $2500 \mathrm{mg}$ cellobiose and $500 \mathrm{mg}$ soluble starch. The medium was brought to a boil under $\mathrm{CO}_{2}$ and cooled. Tryptone peptides (Difco) were added to a final concentration of $10000 \mathrm{mg} . \mathrm{L}^{-1}$. Then $4000 \mathrm{mg}$ of $\mathrm{Na}_{2} \mathrm{CO}_{3}$ and $1 \mathrm{mg}$ resazurin were added and the solution was bubbled with $\mathrm{CO}_{2}$ until the $\mathrm{Na}_{2} \mathrm{CO}_{3}$ dissolved. A solution of $\mathrm{Na}_{2} \mathrm{~S}$ was then added (500 mg. L-1 $\mathrm{Na}_{2} \mathrm{~S} .9 \mathrm{H}_{2} \mathrm{O}$, final concentration). The $\mathrm{pH}$ medium was 6.8 .

The following operations were conducted in three replicates: each tube of Hungate received, in anaerobic conditions, $9 \mathrm{~mL}$ of the medium containing the peptides and $1 \mathrm{~mL}$ of the inoculum previously described. The starting absorbance at 660 $\mathrm{nm}$ was 0.8 . The parameters were measured every hour for $5 \mathrm{~h}$ during the bacterial growth. After measuring the bacterial growth at $660 \mathrm{~nm}$, the samples were stored at $-20^{\circ} \mathrm{C}$ before analysis.

\section{Enzymatic activities}

Total proteolytic activity was measured using azocasein. The incubation time was $6 \mathrm{~h}$. An enzyme unit corresponds to an optical density (OD) variation of 0.01 unit $\mathrm{h}^{-1}$ (Debroas and Blanchart, 1993a). The dipeptidyl aminopeptidase type I like activity (DAP-1) was determined using Gly-Arg4-methoxy-2-naphthylamid (MNA) as the fluorogenous substrate according to the method of Wallace and McKain (1989). The incubation time was $6 \mathrm{~h}$ in anaerobiosis at $39^{\circ} \mathrm{C}$. MNA was determined by its fluorescence (excitation wavelength $=$ $350 \mathrm{~nm}$, emission wavelength $=420 \mathrm{~nm}$ ). The exoaminopeptidase activities were measured on Ala-pNA and Leu-pNA as chromogenous substrates (Wallace and McKain, 1989). The incubation was done in anaerobic conditions for $4 \mathrm{~h}$ at $39{ }^{\circ} \mathrm{C}$. The release of pNA was determined by the diazotization procedure of Appel (1974).

Gly-Arg-MNA, MNA, Leu-pNA, Ala-pNA, pNA and other peptides were from Sigma Chemicals (Saint-Quentin-Fallavier, France).

\section{Chemical analysis}

Ammonia concentration was determined with an ammonia gas sensing electrode (Orion, mode 95-12) and volatile fatty acid (VFA) concentrations were determined by gas-liquid chromatography (GLC) on capillary column (Debroas and Blanchart, 1993b). Lactate was determined using a Sigma diagnosis kit in order to detect Streptococcus bovis in the medium. The productions of VFA, ammoniac and lactate were calculated.

\section{HPLC analysis of peptides}

Samples were centrifuged $(12000 \mathrm{~g}$ for $10 \mathrm{~min}$, $4{ }^{\circ} \mathrm{C}$ ). The supernatant was filtered through a 0.22 $\mu \mathrm{m}$ pore-size-membrane filter (Millipore, SaintQuentin, France) before injection onto the column. Absorbance was measured at $280 \mathrm{~nm}$ in order to avoid the interferences occurring at $220 \mathrm{~nm}$ due to VFA and to other compounds present in the medium (Depardon et al, 1995). As only peptides containing aromatic residues absorb at this wavelength, the fraction of small peptides was probably underestimated. The apparatus was a Beckman system (Instruments Inc, USA) and the peaks were integrated by the Gold computerized system. 
The molecular weight distribution profiles of hydrolysates were determined by high-performance size exclusion chromatography (HPSEC) using a spherogel column SEC $2000(5 \mu \mathrm{m}$, $30 \mathrm{~cm} \times 7.5 \mathrm{~mm}$, Beckman). The pump rate was $0.3 \mathrm{~mL} \mathrm{~min}^{-1}$, the eluent used was a $0.1 \mathrm{M}$ sodium-phosphate buffer $\mathrm{pH} 6.8$ and the run time was $60 \mathrm{~min}$. Standard peptides used for calibration of the column were $\alpha$-lactalbumin (14 000 $\mathrm{Da})$, aprotinin (6 $512 \mathrm{Da})$, streptomycin (1 457 $\mathrm{Da})$, Leu-enkephalin (601 Da) and Phe-Gly-PheGly (426 Da). In order to compare the molecular weight distribution of tryptone peptides during fermentation, integration of the surface of chromatograms obtained by HPSEC was performed. The total surface was separated into four ranges (2 to $4 \mathrm{kDa}, 1$ to $2 \mathrm{kDa}, 0.5$ to $1 \mathrm{kDa}$ and $<0.5 \mathrm{kDa}$ ) expressed as the percentage of the total surface (Turgeon and Gauthier, 1990). The total surface obtained by HPSEC for each time made it possible to express quantitatively the total weight of the residual peptides.

Reverse-phase HPLC was used to separate peptides according to their hydrophobicity. The less hydrophobic peptides were eluted within the first $20 \mathrm{~min}$. A Supelcosil column LC-18 DB $(5 \mu \mathrm{m}$, $25 \mathrm{~cm} \times 4.6 \mathrm{~mm}$, Supelco Inc, USA) was used in the following conditions: solvent $A: 0.1 \%$ trifluoroacetic acid in water $(\mathrm{V} / \mathrm{V})$ and solvent $\mathrm{B}: 0.1 \%$ TFA $(\mathrm{v} / \mathrm{v})$ in acetonitrile/water $(50: 50, \mathrm{v} / \mathrm{v})$. Samples eluted at the rate of $0.8 \mathrm{~mL} \mathrm{~min}-1$. The gradient used was as follows: $0 \mathrm{~min} 0 \% \mathrm{~B}, 15 \mathrm{~min} 30 \% \mathrm{~B}$, $25 \min 40 \%$ B, $35 \min 60 \%$ B, $52 \min 100 \%$ B, $55 \mathrm{~min} 0 \% \mathrm{~B}$ and $63 \mathrm{~min} 0 \% \mathrm{~B}$ end of analysis.

\section{Amino acid analysis}

\section{Hydrolysis}

Two $\mathrm{mL}$ of culture medium was filtred on $0.2 \mu \mathrm{m}$. To each tube was added $2 \mathrm{~mL}$ of $12 \mathrm{~N} \mathrm{HCl}$; the tubes were then flushed with $\mathrm{N}_{2}$ and sealed. The hydrolysis was carried out at $110^{\circ} \mathrm{C}$ for $22 \mathrm{~h}$.

\section{Derivatization}

Derivatization was carried out according to the method of Husek (1991). Forty $\mu \mathrm{L}$ of the sample were mixed with $10 \mu \mathrm{L}$ of the internal standard solution (Norleucine and L-p-chlorophenylalanine 1:1) to a concentration of $1 \mathrm{gL}^{-1}, 10 \mu \mathrm{L}$ of $0.1 \mathrm{~N} \mathrm{HCl}$ and $40 \mu \mathrm{L}$ of an ethanol-pyridine mixture $(4: 1) ; 5 \mu \mathrm{L}$ of ethyl chloroformate (ECF) was added. After shaking, $0.1 \mathrm{~mL}$ of chloroform-ECF ( $1 \%$ ECF) solution was added. The upper phase was discarded.

\section{Analysis}

The injector and flame ionization detector temperatures were both $250^{\circ} \mathrm{C}$. Helium was used as the carrier gas. The capillary column employed was OV 1701 (25 m x $0.32 \mathrm{~mm}$ ) (Spiral, Dijon, France). The temperature was monitored to increase from $145^{\circ} \mathrm{C}$ to $205^{\circ} \mathrm{C}$ with a linear slope of $12.5^{\circ} \mathrm{C} \mathrm{min}^{-1}$ and to reach the end temperature of $260^{\circ} \mathrm{C}$ with a linear slope of $5^{\circ} \mathrm{C} \mathrm{min}^{-1}$. The factor response of each amino acid was computed after analysis of serial dilution of standard solution (AAS18, Sigma).

\section{Statistical analysis}

Analysis was made hourly on three tubes sampled during the bacterial growth. The data from the kinetic studies were submitted to a normalized principal component analysis (PCA) applied to growth curves according to Estève and Schifflers (1974) and Porretta and Vicini (1993). The time effects on the amino acid composition were tested using the Kruskal-Wallis test.

\section{RESULTS}

\section{Enzymatic and fermentation activities}

The total proteolytic activity as well as the main peptidase activities are shown in figures 1 and 2 . The total proteolytic activity increased during the exponential phase of the bacterial growth. The DAP-1 like activity observed at the beginning of incubation was already high (release of MNA: $10.1 \mu \mathrm{M}$ ). It multiplied by two during the first hour of incubation and then remained rather constant throughout the bacterial growth. Both leucine and alanine aminopeptidase activities exhibited a maximum increase in the middle of the exponential phase and decreased quickly at the end of this phase. All the proteolytic activities decreased over the stationary phase. 
The amount of ammonia in the medium increased during the first $2 \mathrm{~h}$ and then decreased to reach the pre-incubation value at the end of incubation (fig 3).

Acetic, propionic and butyric acid contents compared with the initial values increased during the incubation in proportions 12:6:1 (table I). The concentrations of branched VFA (isobutyrate and isovalerate) were always higher than at the beginning of the fermentation. Lactate accumulated rapidly during the exponential phase of the bacterial growth.

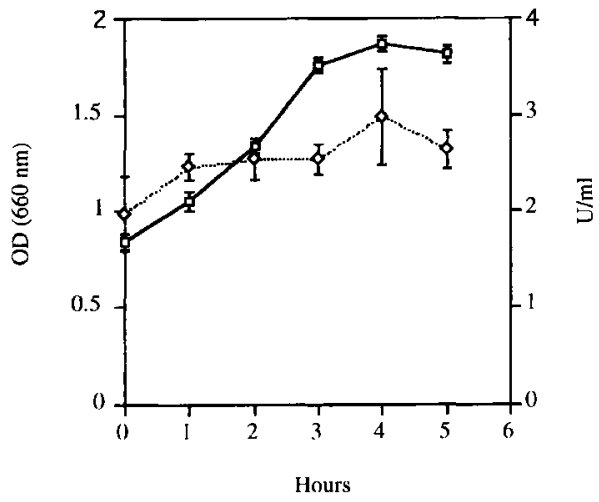

Fig 1. Bacterial growth measured at $660 \mathrm{~nm}$ (- - and total proteolytic activity in $\mathrm{U} / \mathrm{mL}$ $(-\nabla-)$ during fermentation.

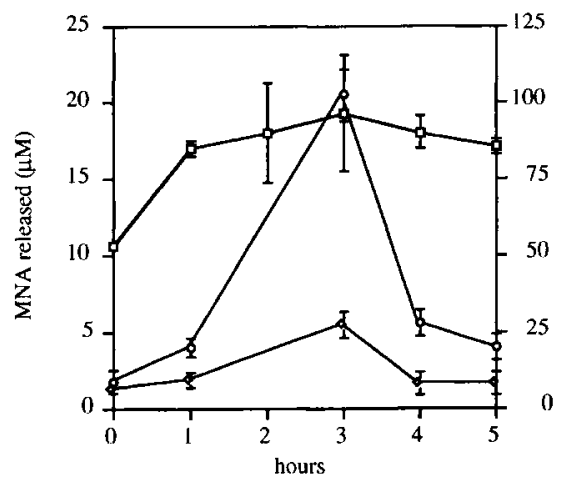

Fig 2. Peptidase activities measured during fermentation: (- $\square-$ ) Gly-Arg-MNA; $(\cdots \circ \cdots)$ AlapNA; (---O---) LeupNA.
The breakdown of the peptides was progressive throughout the bacterial growth (fig 4). In late incubation, $33 \%$ of the peptides had disappeared.

\section{Molecular weight distribution of peptides}

Figure 5 shows the molecular weight distribution of the peptides present in the supernatant in early and late fermentation. The chromatograms are composed of three major peaks corresponding to peptides of decreasing molecular weight. During the fermentation the first peak ( 2 to $4 \mathrm{kDa}$ ), and to a lesser extent, the second one $(0.5$ to $2 \mathrm{kDa}$ ) decreased whereas the last one $(<0.5 \mathrm{kDa})$ remained stable. The fraction of small peptides $(<0.5 \mathrm{kDa}$ ) represented $60 \%$ of the peptides present after $5 \mathrm{~h}$.

\section{Distribution of peptides according to their hydrophobicity}

Hydrophilic materials eluted earlier from reverse-phase columns than hydrophobic

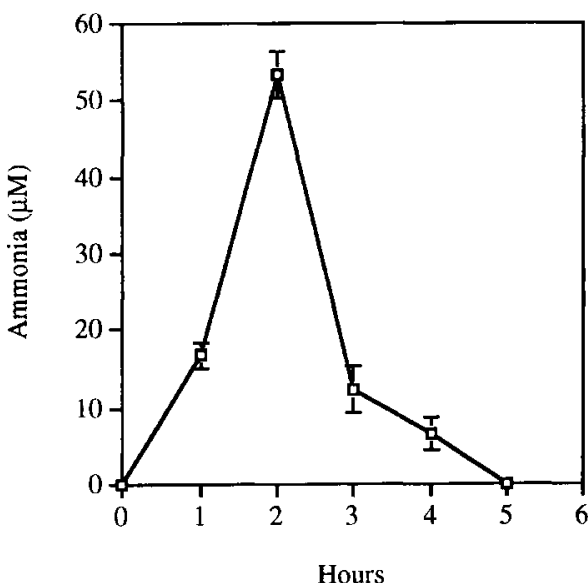

Fig 3. Ammonia content above the values at the beginning of incubation. 
Table I. Concentrations of VFA $(\mu \mathrm{mol} / \mathrm{mL})$ and lactate $(\mu \mathrm{mol} / \mathrm{mL})$ during fermentation.

\begin{tabular}{|c|c|c|c|c|c|c|c|}
\hline & $C_{2}$ & $c_{3}$ & $i C_{4}$ & $C_{4}$ & $i C_{5}$ & $C_{5}$ & Lactate \\
\hline $1 \mathrm{~h}$ & $1.53 \pm 0.33$ & $0.57 \pm 0.13$ & $0.079 \pm 0.010$ & $0.24 \pm 0.05$ & $0.23 \pm 0.05$ & $0.08 \pm 0.01$ & $10.33 \pm 0.040$ \\
\hline $2 \mathrm{~h}$ & $2.79 \pm 0.17$ & $1.51 \pm 0.13$ & $0.085 \pm 0.005$ & $0.37 \pm 0.03$ & $0.34 \pm 0.01$ & $0.11 \pm 0.01$ & nd \\
\hline $3 \mathrm{~h}$ & $4.32 \pm 0.25$ & $2.45 \pm 0.03$ & $0.149 \pm 0.003$ & $0.39 \pm 0.00$ & $0.25 \pm 0.01$ & $0.07 \pm 0.00$ & $75.55 \pm 10.00$ \\
\hline $4 \mathrm{~h}$ & $10.16 \pm 0.28$ & $5.08 \pm 0.07$ & $0.133 \pm 0.003$ & $0.81 \pm 0.01$ & $0.28 \pm 0.01$ & $0.09 \pm 0.00$ & $74.67 \pm 2.70$ \\
\hline $5 \mathrm{~h}$ & $7.77 \pm 0.77$ & $4.25 \pm 0.37$ & $0.136 \pm 0.004$ & $0.51 \pm 0.04$ & $0.28 \pm 0.02$ & $0.08 \pm 0.01$ & $70.89 \pm 1.41$ \\
\hline
\end{tabular}

nd: not determined.

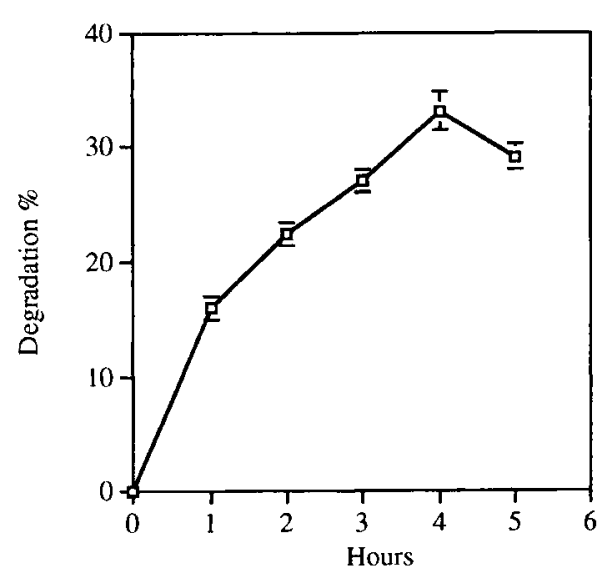

Fig 4. Breakdown of tryptone peptides during fermentation. residues. The chromatograms (fig 6) show that tryptone peptides are represented by a burst of peaks in the hydrophilic area whereas the hydrophobic fraction is poorly represented. The peak eluted at $33 \mathrm{~min}$ is not a peptide but an impurity (1). The most hydrophilic peak (9.7 $\mathrm{min}$ ) (2), as well as those eluted between 12 and $16 \min (3)$, disappeared during the fermentation. Peaks corresponding to peptides with a moderate (17 min) (4) and a high (32 min) (5) hydrophobicity decreased whereas peptides of very different hydrophobicity degrees (from 10 to $12 \mathrm{~min}, 24,35$ and $39 \mathrm{~min}$ ) remained undegradated during the fermentation. The greatest declines were observed in peaks that eluted early.

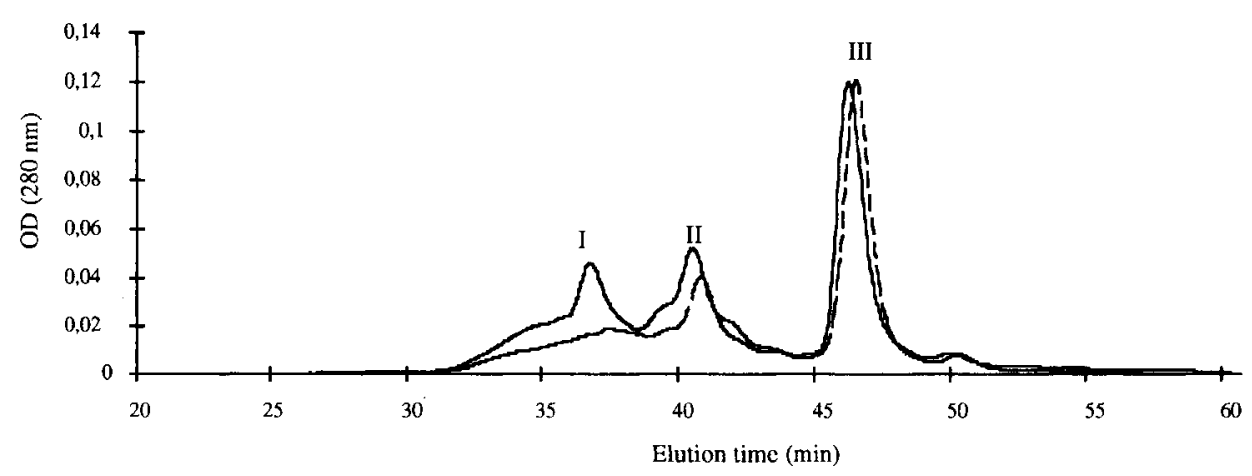

Fig 5. Elution profiles by high-performance size exclusion chromatography of tryptone peptides in early $t=0 \mathrm{~h} \mathrm{(-)}$ and late $t=5 \mathrm{~h} \mathrm{(--)}$ incubation. Fraction I: 2 to $4 \mathrm{kDa}$; fraction II: 0.5 to $2 \mathrm{kDa}$; and fraction III: $<0.5 \mathrm{kDa}$. 


\section{Change in amino acid composition of the residual peptide of tryptone}

The effect of rumen bacteria on tryptone amino acids is shown in table II. During the fermentation, valine increased in peptide residue, while phenylalanine decreased. The mean proportions of serine and lysine were higher and histidine, threonine and $G L x$ were lower in peptide residue compared to their proportion at $t=$ oh $(P<0.10)$.

\section{DISCUSSION}

Molecular weight of peptides, enzymatic activities and fermentation activities

Tryptone peptides were incompletely hydrolyzed $(33 \%)$ after $5 \mathrm{~h}$ of incubation.
This result agreed with those found for tryptone, an enzymatic digest of casein, by Yang an Russell (1992). These authors observed that when mixed ruminal bacteria were incubated in vitro with casein hydrolysate, many peptides were never utilized even after $96 \mathrm{~h}$ incubation. They concluded that some peptides were resistant to ruminal hydrolysis.

Among the exopeptidase activities measured before incubation, only the DAP-1 activity was very high. In the rumen, this activity would only be due to Prevotella ruminicola (Wallace and McKain, 1991; McKain et al, 1992). The proteolytic activity (or endopeptidase activity) detected using the azocasein procedure is also present before incubation $(t=0 \mathrm{~h})$. The breakdown of peptides by rumen bacteria started from the first hour of fermentation.

The data from the kinetic studies were submitted to a normalized PCA (fig 7). The two significant axes (F1, F2) allowed the explanation of $86.5 \%$ of the variance. F1
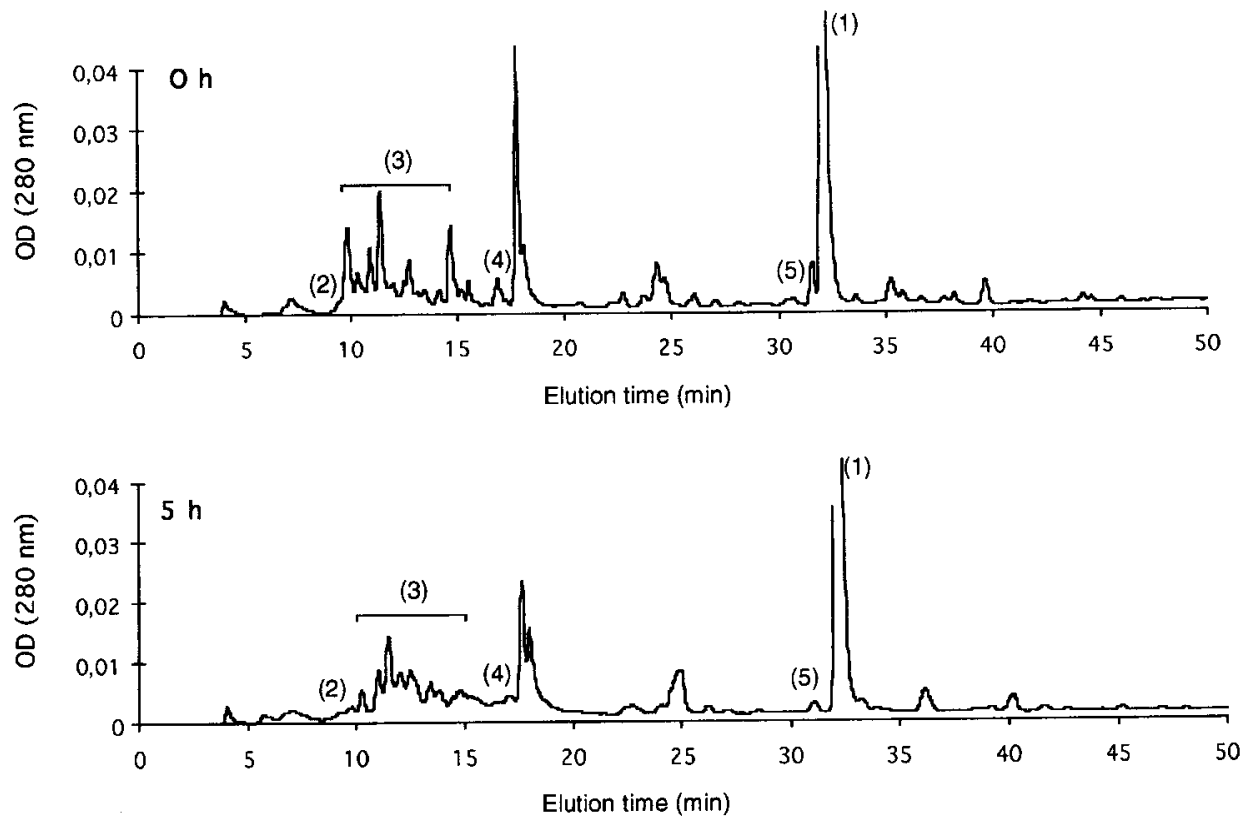

Fig 6. Chromatograms obtained by reverse-phase high-performance liquid chromatography (LC-18 $\mathrm{DB}$ ) of peptides in early (top: $t=0 \mathrm{~h}$ ) and late (bottom: $t=5 \mathrm{~h}$ ) incubation. 
Table II. Amino acid composition (\%) of degradation-resistant peptides.

\begin{tabular}{lrrrr}
\hline & \multicolumn{1}{c}{ oh } & $2 h$ & $5 h$ & $\mathrm{P}^{\star}$ \\
\cline { 1 - 1 } & & & & \\
\hline Phob & & & & \\
Ala & 3.84 & 3.96 & 3.67 & 0.32 \\
Gly & 2.62 & 2.62 & 2.26 & 0.32 \\
Val & 5.79 & 6.30 & 6.46 & 0.09 \\
Leu & 8.35 & 8.76 & 8.06 & 0.09 \\
lle & 5.34 & 5.80 & 5.79 & 0.13 \\
Pro & 9.68 & 9.77 & 10.37 & 0.26 \\
Met & 3.77 & 4.02 & 4.06 & 0.20 \\
Phe & 6.56 & 6.47 & 5.85 & 0.08 \\
Phil & & & & \\
Thr & 4.53 & 4.56 & 4.01 & 0.08 \\
Ser & 6.43 & 6.54 & 7.82 & 0.06 \\
Glx & 17.33 & 14.10 & 12.29 & 0.09 \\
Asx & 6.54 & 6.96 & 7.84 & 0.40 \\
Lys & 12.87 & 13.93 & 16.22 & 0.08 \\
His & 3.56 & 3.26 & 2.35 & 0.08 \\
Tyr & 2.79 & 2.96 & 2.95 & 0.70 \\
& & & & \\
\hline
\end{tabular}

Phob: hydrophobic amino acids; Phil: hydrophilic amino acids. "Probability determined by the Kruskal-Wallis test.

integrated the DAP-1 activity, total proteolytic activity and the concentration of the $<0.5 \mathrm{kDa}$ peptidic fraction. The concentration of the $>0.5 \mathrm{kDa}$ fraction correlated neg- atively with the aforementioned variables. Correlation with optical density reflected a temporal depolymerization of high molecular weight peptides against those of the $<0.5 \mathrm{kDa}$ fraction. These degradation abilities were closely linked to both total proteolytic and DAP-1 activities. Clearly, the newly resulting $<0.5 \mathrm{kDa}$ fraction was chiefly DAP-1-related. The breakdown of the peptides was essentially due to the endopeptidase and DAP-1 like activities. This emphasizes the role of Prevotella ruminicola on peptide breakdown. F2 integrated the leucine- and alanine-based aminopeptidase activity together with the production of ammonia. The nonspecific exoaminopeptidase activity measured by Alap $\mathrm{Na}$ and the specific leucine aminopeptidase (LAP) activity clearly increased in the culture medium after only $1 \mathrm{~h}$ incubation. Both activities presented the same profile with a maximum over the third hour of fermentation, that is, in the middle of the exponential phase, but they differed in their bacterial origin. The nonspecific activity was observed in numerous rumen strains (Wallace and McKain, 1991), whereas LAP activity was only expressed by Streptococcus bovis and to a lesser extent by Ruminobacter amy-

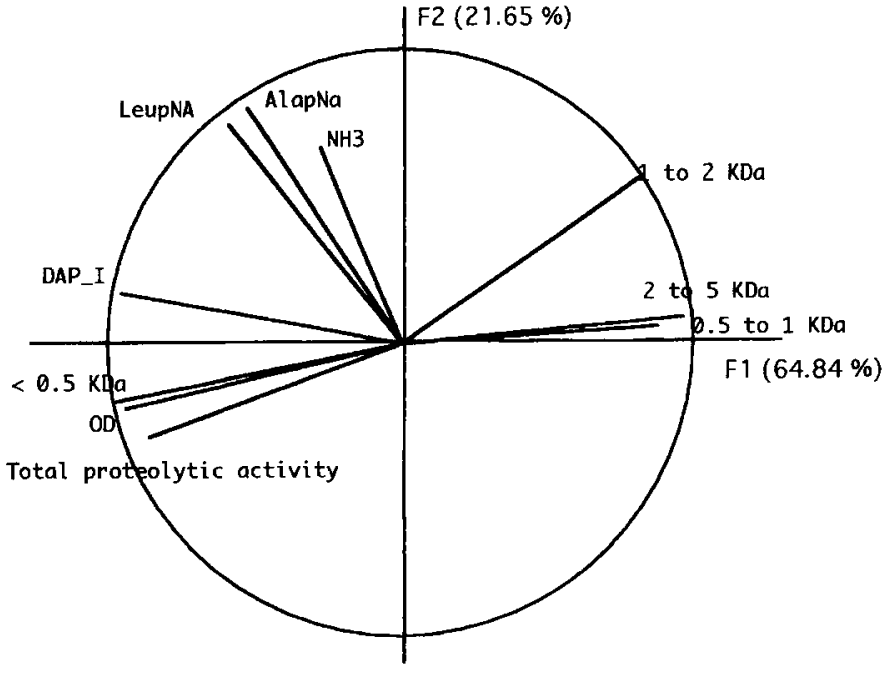

Fig 7. Plot on the plane of the first two principal components of the enzymatic activities and molecular weight of peptides. 
lophilus (Wallace and McKain, 1991). Production of lactate in mid-fermentation suggests that the LAP activity might be attributed chiefly to Streptococcus bovis. This bacterial species might thus play a significant role in the enzyme breakdown of peptides in vivo. It should be noted that these activities did not persist during all of the bacterial growth. They decreased considerably between 3 and $4 \mathrm{~h}$. In contrast, the difference between ammonia production and utilization exhibited a maximum in the mid-exponential phase, which emphasized a high deaminase activity. Prevotella ruminicola is also considered as one of the bacteria species able to produce ammonia from protein hydrolysate (Bladen et al, 1961). The production of branched VFA during the fermentation emphasized the metabolism of ramified amino acids.

The peptides with the highest molecular weight were apparently more degraded. Like Wallace in 1992, we observed an intensive conversion of high molecular weight peptides to small-sized peptides ( $0.5 \mathrm{kDA})$. Bacteria can only assimilate peptides with a molecular weight lower than $750 \mathrm{Da}$ (Wesltlake and Mackie, 1990). In our study the proportion of peptides in this range of molecular weight increased, indicating that the production of those small peptides was higher than their captation by bacteria. Thus, assimilation of small peptides in vitro is probably the limiting step of casein proteolysis.

\section{Distribution of peptides according to their hydrophobicity and amino acid composition}

The separation of peptides by LC18DB column indicated that there is an increase of the proportion of some peptides, as shown by one peak emerging in the hydrophilic area (12 $\mathrm{min})$ and three others in the hydrophobic area (24, 36 and $39 \mathrm{~min})$. The persistence of peaks in the hydrophobic area agrees with the data from the literature, but the same result in the case of a hydrophilic peptides has never been reported. Hydrophobic peptides are known to be used less rapidly than hydrophilic peptides (Chen et al, 1987b, c). Separation of tryptone peptides by reverse-phase HPLC showed a preferential disappearance of hydrophilic peptides over hydrophobic ones. In contrast, amino acid profiles indicated that hydrophilic amino acids were not taken up significantly faster than the hydrophobic amino acids by mixed ruminal bacteria. These observations conflict with the previous results. Absorbance was measured at 280 $\mathrm{nm}$ in order to avoid the interferences occurring at $220 \mathrm{~nm}$. Therefore, only peptides containing aromatic residues absorbed at this wavelength and consequently the fraction of small peptides were underestimated. Other factors bound to the primary structure of peptides might play an important role in the breakdown and assimilation by the bacteria. It has been shown that proline-rich peptides are degraded more slowly than neutral peptides (Broderick et al, 1988; Yang and Russel, 1992). Our experiments indicated that peptide residue was not significantly enriched in proline.

From our study peptide size and hydrophobicity were shown to be two determining factors of the metabolism of peptide. Studying the primary structure of peptides that offer resistance to the rumen bacteria should give a better understanding of the factors affecting peptide metabolism in the rumen. Our study confirmed the predominant role of Prevotella ruminicola in the peptide degradation. The LAP activity did not persist all during the bacterial growth, but, instead, sharply declined after $4 \mathrm{~h}$. This suggests that the LAP activity might be subjected to a regulation and thus makes it difficult to define the role of Streptococcus bovis in peptide degradation. It also strengthens the conclusions of Wallace and McKain (1991) who have shown that the proteolytic 
activity of Streptococcus bovis might be relatively small in the rumen. In order to define which structural features govern how peptides are susceptible to degradation, individual resistant peptides, such as those that appeared in the $\mathrm{C}_{18}$ chromatograms, could be isolated and sequenced.

\section{REFERENCES}

Appel W (1974) Peptidases. In: Methods of Enzymatic Analysis, $2 d$ edn (H Bergmeyer, ed), Academic Press, Inc, New York, 2, 949-979

Bladen HA, Bryant MP, Doetsch RN (1961) A study of bacterial species from the rumen which produce ammonia from protein hydrolysate. Appl Microbiol $9,175-180$

Broderick GA, Wallace RJ, McKain N (1988) Uptake of small neutral peptides by mixed rumen microorganisms in vitro. J Sci Food Agric 42, 109-118

Chen G, Russell JB, Sniffen CJ (1987a) A procedure for measuring peptides in rumen fluid and evidence that peptide uptake can be a rate limiting step in ruminal protein degradation. J Dairy Sci 70,1211 1219

Chen G, Sniffen CJ, Russel JB (1987b) Concentration and estimated flow of peptides from the rumen of dairy cattle: effects of protein quantity, protein solubility. J Dairy Sci 70, 983-992

Chen G, Strobel HJ, Russell JB, Sniffen CJ (1987c) Effect of hydrophobicity on utilization of peptides by ruminal bacteria in vitro. Appl Environ Microbiol 53, 2021-2025

Copper PB, Ling JR (1985) The uptake of peptides and amino acids by rumen bacteria. Proc Nutr Soc 44, 144

Debroas D, Blanchart G (1993a) Characteristics of extracellular protease formation by a rumen microorganism Clostridium bifermentans and its possible role in the hydrolysis of proteins in the rumen. Microbiol Alim Nutr 11, 101-109

Debroas D, Blanchart G (1993b) Interactions between proteolytic and cellulolytic rumen bacteria during hydrolysis of plant cell wall protein. Reprod Nutr Dev 30, 493-505

Depardon N, Debroas D, Blanchart D (1995) Breakdown of peptides from a soya protein hydrolysate by rumen bacteria. Simultaneous study of enzyme activities and of two physico-chemical parameters: molecular weight and hydrophobicity. J Sci Food Agric 68, 25-31
Estève J, Schifflers E (1974) Some aspects of growth in laboratory mice (statistical analysis of a family of growth curves). Ann Zool Ecol Anim 6, 449-462

Hungate RE (1969) A role tube method for cultivation of strict anaerobes. Methods Microbio/ 3B, 117-132

Husek P (1991) Rapid derivatization and gas chromatographic determination of amino acids. J Chromatograph 552, 289-299

McKain N, Wallace RJ, Watt ND (1992) Selective isolation of bacteria with dipeptidyl aminopeptidase type I activity from the sheep rumen. FEMS Microbiol Lett 95, $169-174$

Porretta S, Vicini E (1993) Changes in tomato pulp quality caused by lactic acid bacteria. Int J Food Sci Technol 28, 611-616

Russell JB, Sniffen CJ, Van Soest PJ (1983) Effect of carbohydrate limitation on degradation and utilization of casein by mixed rumen bacteria. J Dairy Sci 66, 763-775

Schaefer DM, Davis CL, Bryant MP (1980) Ammonia saturation constants for predominant species of rumen bacteria. J Dairy Sci 63, 1248-1263

Turgeon SL, Gauthier SF (1990) Whey peptide fractions obtained with a two-step ultrafiltration process: production and characterization. J Food Sci 55, 106-110

Wallace RJ (1992) Gel filtration studies of peptide metabolism by rumen microorganisms. J Sci Food Agric 58, 177-184

Wallace RJ, McKain N (1989) Analysis of peptide metabolism by ruminal microorganisms. Appl Environ Microbiol 55, 2372-2376

Wallace RJ, McKain N (1991) A survey of peptidase activity in rumen bactria. $J$ Gen Microbiol 137, 22592264

Wallace RJ, McKain N, Newbold CJ (1990a) Metabolism of small peptides in rumen fluid. Accumulation of intermediates during hydrolysis of alanine oligomers, and comparison of peptidolytic activities of bacteria and protozoa. $J$ Sci Food Agric 50, 191-199

Wallace RJ, Newbold CJ, McKain N (1990b) Patterns of peptide metabolism by rumen microorganisms. In: The Rumen Ecosystem. The Microbial Metabolism and Its Regulation (S Hoshino, R Onodera, H Minato, H Itabashi, eds), Japan Scientific Societies Press, Tokyo, Japan, 43-49

Westlake K, Mackie RI (1990) Peptide and amino acid transport in Streptococcus bovis. Appl Microbiol Biotechnol 34, 97-102

Wright DE (1967) Metabolism of peptides by rumen microorganisms. Appl Microbiol 15, 547-550

Yang CMJ, Russell JB (1992) Resistance of prolinecontaining peptides to ruminal degradation in vitro. Appl Environ Microbiol 58, 3954-3958 